\title{
Population status, distribution and conservation needs of the narrow-striped mongoose Mungotictis decemlineata of Madagascar
}

\author{
Lance Woolaver, Rina Nichols, William F. Rakotombololona, Anselme T. Volahy and Joanna Durbin
}

\begin{abstract}
The narrow-striped mongoose Mungotictis decemlineata is a small, endemic carnivore currently known to occur only in the dry deciduous forests of the central and southern Menabe regions of western Madagascar. It is categorized as Endangered on the IUCN Red List and is threatened by rapid habitat loss from deforestation. From live-trapping and village surveys we found $M$. decemlineata to be distributed throughout the largest area of connected forest in central Menabe and most of the larger forest fragments in southern Menabe. We estimated there are a minimum of 2,000-3,400 adults in central Menabe and 6,400-8,650 adults in southern Menabe. Although this represents the total known population, the southern limits of the species' range are still unclear. Fifty-four individuals were live-trapped in central Menabe. $M$. decemlineata abundance was not correlated with forest structure or
\end{abstract}

\section{Introduction}

The narrow-striped mongoose Mungotictis decemlineata, or boky-boky in Malagasy, is a small carnivore currently known to occur only in the dry deciduous forests of the Menabe region of western Madagascar. This species is categorized as Endangered on the IUCN Red List (IUCN, 2004) and is threatened by the rapid loss of habitat through deforestation. Total forest loss in the Menabe region between 1963 and 1993 was 32\%, a result of agroindustrial projects and slash-and-burn cultivation (Tidd et al., 2001). Forest loss has continued since 1993 at an accelerated rate (J. Pinder, unpubl. data). There are two currently recognized subspecies, $M$. $d$. decemlineata and M. d. lineata, the latter known from a single immature specimen (Gray, 1848) from an unspecified locality in Madagascar. M. d. decemlineata in central and southern Menabe are believed to be two distinct subpopulations (Hawkins et al., 2000).

\footnotetext{
Lance Woolaver (Corresponding author) and Rina Nichols Wildlife Preservation Canada, 120 King Street, Guelph, Ontario, N1E 4P8, Canada. E-mail lancewoolaver@hotmail.com
}

William F. Rakotombololona, Anselme T. Volahy and Joanna Durbin Durrell Wildlife Conservation Trust, BP 8511, Antananarivo (101), Madagascar.

Received 12 July 2004. Revision requested 5 January 2005. Accepted 27 April 2005 invertebrate abundance and diversity at the sampled sites. The building of access roads for logging may have a long-lasting effect by increasing the level of human disturbance, predation by domestic dogs, and illegal cutting within the surrounding area. Conservation management efforts to save $M$. decemlineata need immediate implementation, with emphasis on cooperative efforts with local villages to reduce the rate of slash-and-burn agriculture and logging of the remaining dry deciduous forest of the region. Research to determine population trends and status of $M$. decemlineata south of the Morondava and Mangoky rivers is required.

Keywords Distribution, Madagascar, Mungotictis decemlineata, narrow-striped mongoose, population status.
M. decemlineata is a social animal that lives in family units. Groups of 3-5 adults may be observed together with juveniles during the dry season (June-October). Solitary animals and groups of one adult with one juvenile are more commonly observed during the warmer wet season (Rabeantoandro, 1997). Mating occurs from July to December. A gestation period of 74-106 days is generally followed by the birth of a single infant (Albignac, 1973; Razafimanantsoa, 2003). M. decemlineata is primarily insectivorous, but their diet is supplemented by small mammals, reptiles and birds (Rabeantoandro, 1997). Larger prey items such as mouse lemurs (Microcebus spp.) may be cooperatively hunted by groups (Albignac, 1976). Specialization on insect larvae may help them survive during the dry season when the availability of other food items is limited (Albignac, 1976).

Field research was carried out during AugustNovember 2002 to address the lack of knowledge of the current distribution and abundance of $M$. decemlineata and to determine threats to the species' survival. This paper reports the findings of this research.

\section{Methods}

The study was conducted in western Madagascar within central and southern Menabe (Fig. 1). Central Menabe extends from south of the Tsiribihina River to north of the Morondava River (Fig. 2). Southern Menabe extends 


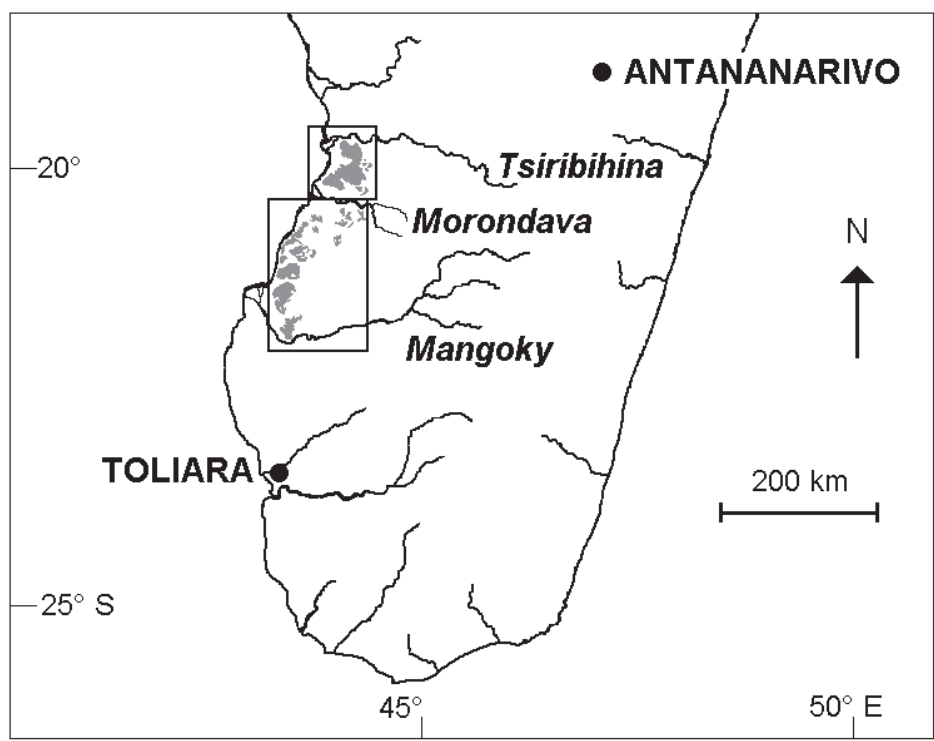

Fig. 1 Southern Madagascar showing the main rivers and study areas of central (see Fig. 2) and southern Menabe (see Fig. 3).

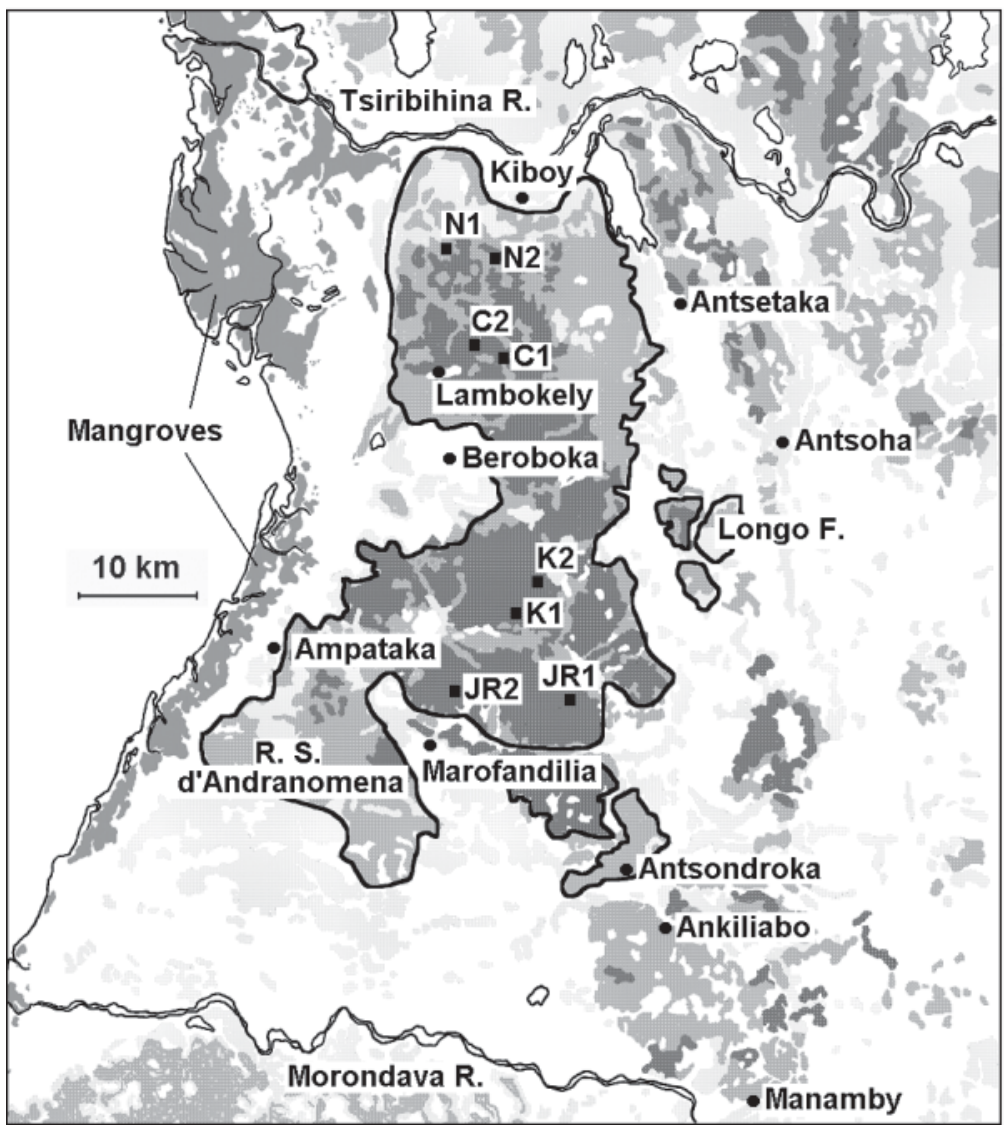

Fig. 2 Central Menabe (see Fig. 1), with locations of study plots and major villages. The distribution of $M$. decemlineata is delimited by the solid black line. Forest quality is shown in shades of grey with dense forest represented by the darkest grey and highly degraded forest represented by the lightest grey. The map is adapted from J. Pinder (unpubl. data) and is based on satellite images from 2000. from south of the Morondava River to north of the Mangoky River (Fig. 3).

Twenty-eight villages in southern Menabe and five villages in central Menabe were visited over AugustNovember 2002 to determine range limits. A group interview was conducted during a meeting at each village, with participation by 6-14 village leaders. Topographic maps (scale 1:100,000 and 1:300,000) and photographs of Malagasy animals were used as aids. Villagers were asked to name the areas of forest they utilized, describe their activities (honey collection, Tenrec hunting or other activities) and name animals they encountered in the 


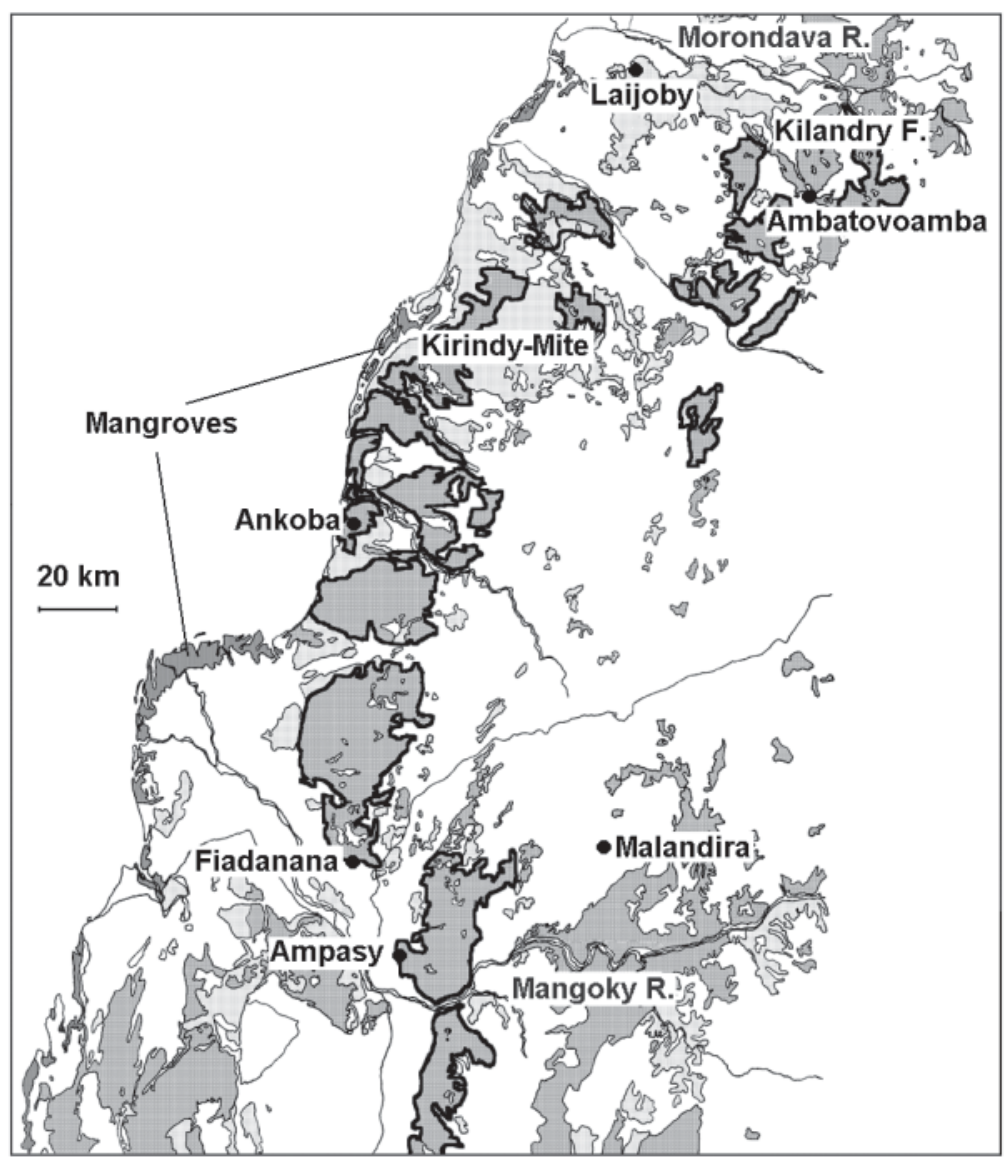

Fig. 3 Southern Menabe (see Fig. 1), with major villages. The distribution of $M$. decemlineata is delimited by the solid black line. Forest quality is shown in shades of grey with dense forest represented by the darker grey and degraded forest represented by the lighter grey. The map is adapted from T.H. Andrianandrasana (unpubl. data) and is based on satellite images from 1996. forest. If boky-boky was not mentioned, villagers were asked to identify photographs of forest animals. If bokyboky was recognized the conversation was directed more specifically towards boky-boky and, if not, villagers were directly asked if they knew of boky-boky.

Eight 16 ha plots were live-trapped over OctoberNovember 2002 in central Menabe. Plots were divided among four different sites with two plots per site. Within each site one plot was in exploited forest (either commercially cut and/or cut heavily by villagers) and the other in relatively unexploited forest. Sites were located throughout the remaining intact dry deciduous forest (Fig. 2). Trapping was discontinued at the end of November to avoid capturing pregnant females or females with newborns. Trapping could not be carried out in southern Menabe. Trap stations were $100 \mathrm{~m}$ apart in a grid pattern of $5 * 5$ stations. Edges of each plot were at least $100 \mathrm{~m}$ from the nearest road or change in habitat. Two live-traps, one larger Tomahawk 205 (Tomahawk Live Trap Co., Tomahawk, Wisconsin, USA) and one smaller Tomahawk 201, were set at each station. Traps were set continuously for 5 days and 5 nights and baited with fermented, salted fish. Daily trap checks were started at 06.00 and 16.00 .
Animals were weighed to the nearest $5 \mathrm{~g}$ using a handheld Pesola balance (PESOLA AG, Baar, Switzerland) and marked by trimming a patch of fur from the body to enable identification of individuals. Sex, age, breeding and general condition, and pelage markings were recorded for each animal. Animals were grouped into three age classes: adults, juveniles ( $>1$ year old but not yet breeding), and young of the year ( $<1$ year old). Animals weighing more than $450 \mathrm{~g}$ with yellow, worn teeth were considered adults (Albignac, 1976). Evidence of breeding condition such as large testes or pregnancy and well-developed mammae also identified them as adults. Animals weighing more than $325 \mathrm{~g}$ that were not in breeding condition and had sharp, clean teeth with little wear, were considered juveniles. Young of the year were obvious because of their small body mass (generally $<325 \mathrm{~g}$ ) and at least some white milk teeth comprising a portion of their dentition (Albignac, 1976).

Time within each study area was standardized among the eight plots, with c. 40 person hours of trap checking and c. 72 person hours of habitat and invertebrate sampling per plot. Group sizes and number of $M$. decemlineata encountered in the forest at each plot were therefore considered to be reliable indices of relative abundance. Observations included all animals encountered and 
trapped within the area covered by each trapping grid. Untrapped animals that remained in the immediate area while we handled a trapped animal were considered to be part of the same group. Trapping effort for each 16 ha plot covered an area substantially larger than the plot itself, allowing for immigration from outside the plot (Krebs, 1999). On two separate occasions marked animals were observed $c .300 \mathrm{~m}$ outside a plot, suggesting that plots were each covering an area of at least $1 \mathrm{~km}^{2}$ (plot size of $400 \mathrm{~m}$ plus $300 \mathrm{~m}$ on each side). The actual area of forest sampled by each plot was therefore estimated to be 100 ha $\left(1 \mathrm{~km}^{2}\right)$. Extent of occurrence and area of occupancy, following IUCN guidelines (IUCN, 2001), were calculated using the geographical information system ArcView v. 3.2 (CSRI, Redlands, USA).

Forested area in central Menabe was calculated, using ArcView, from maps of the region created by J. Pinder (Colorado State University, USA) based on satellite images from 2000. Forest quality assessment followed that suggested by J. Pinder and ranged from dense intact to highly degraded forest. Forested area in southern Menabe was calculated by T.H. Andrianandrasana, using the geographical information system MapInfo Professional v. 5.0 (Troy, New York, USA), and based on satellite images from 1996.

A minimum population density was estimated for each study site based on the number of individuals trapped at each of the two plots at the site. For example, one adult was caught at plot N1 and three adults at plot N2 in Ambatomainty. Because each plot sampled an area of $1 \mathrm{~km}^{2}$, the density at the site of Ambatomainty was $1-3$ adults per $\mathrm{km}^{2}$. The population density for Ambatomainty was then extrapolated to forest of similar quality in that region of central Menabe. It is not likely that all animals were captured within each plot so these estimates should be considered minimum population estimates.

As trapping was not carried out in southern Menabe, minimum densities for the southern region were calculated by extrapolating from the number of animals trapped in forest of similar quality in central Menabe. Although the Schnabel method for estimating abundance (Krebs, 1999) would have been preferable for calculating population estimates, the number of recaptures in the majority of plots were too few to allow for this type of analysis.

Habitat variables were sampled along two transects at each live-trapping plot to describe forest structure (Table 1). Transects were $150 * 4 \mathrm{~m}$ and were parallel to and $100 \mathrm{~m}$ from the associated plot. Each transect was subdivided into $10 \mathrm{~m}$ intervals. All habitat variables (Table 1) were estimated at each $10 \mathrm{~m}$ interval, except for the number of trees and pieces of coarse woody debris, which were counted within each of the intervals.
Table 1 Habitat variables measured at M. decemlineata study plots in central Menabe (Fig. 2) in 2002.

\begin{tabular}{|c|c|}
\hline Code & Variables (adapted from Hawkins \& Wilmé 1996) \\
\hline $\mathrm{T}<5$ & Number of trees $<5 \mathrm{~m}$ in height \\
\hline T5-10 & Number of trees $5-10 \mathrm{~m}$ in height \\
\hline T10-20 & Number of trees $10-20 \mathrm{~m}$ in height \\
\hline $\mathrm{T} 20+$ & Number of trees $>20 \mathrm{~m}$ in height \\
\hline Wd5-20 & $\begin{array}{l}\text { Number of pieces of coarse woody debris with } \\
\text { diameter } 5-20 \mathrm{~cm}\end{array}$ \\
\hline $\mathrm{Wd} 20-40$ & $\begin{array}{l}\text { Number of pieces of coarse woody debris with } \\
\text { diameter } 20-40 \mathrm{~cm}\end{array}$ \\
\hline Wd $40+$ & $\begin{array}{l}\text { Number of pieces of coarse woody debris with } \\
\text { diameter }>40 \mathrm{~cm}\end{array}$ \\
\hline Lianas & $\begin{array}{l}\text { Abundance of lianas (abundant, } 66-100 \% \\
\text { frequent, } 33-66 \% \text {; rare } \leq 33 \% \text { ) }\end{array}$ \\
\hline Litter & Leaf litter depth $(0-1 \mathrm{~cm}, 1-2 \mathrm{~cm}, 2-3 \mathrm{~cm},>3 \mathrm{~cm})$ \\
\hline Canopy & Estimated $\%$ of overhead canopy cover to nearest $5 \%$ \\
\hline Herb & $\begin{array}{l}\text { Estimated \% of herbaceous cover to nearest } 5 \% \\
\text { (projected to ground) }\end{array}$ \\
\hline Shrub & $\begin{array}{l}\text { Estimated \% of shrub cover to nearest } 5 \% \\
\quad \text { (projected to ground) }\end{array}$ \\
\hline Visibility & $\begin{array}{l}\text { Distance visible through vegetation at eye level } \\
\text { (mean of estimates in four directions) }\end{array}$ \\
\hline
\end{tabular}

Leaf litter invertebrates were sampled at each livetrapping plot using pitfall traps. Two $150 \mathrm{~m}$ transects were sampled at each plot with each trap $10 \mathrm{~m}$ apart along each transect. The traps were cups with an aperture diameter of $70 \mathrm{~mm}$, a base diameter of $45 \mathrm{~mm}$ and a depth of $110 \mathrm{~mm}$. The top of the cup was placed flush with the soil, 1/3 full with water and detergent, and covered by a leaf. The pitfalls and invertebrates were collected after $72 \mathrm{~h}$. Invertebrates were identified to the level of Order.

Two $500 * 4 \mathrm{~m}$ transects were surveyed in each trapping plot to record the number of locally and commercially cut trees. Distance from each plot to the three nearest villages was recorded with a global positioning system. The numbers of villagers and dogs encountered near and within the study plots were also recorded.

All data sets were tested for normality using Q-Q plots and histograms of the standardized residuals. Data that did not conform to a normal distribution were either natural $\log$ or square root transformed. SPSS software v. 10.0 (SPSS, Chicago, USA) was used for all analyses. The effect of site and treatment (exploited vs unexploited forest) on number of $M$. decemlineata captured was evaluated using one-way ANOVA. Variation in habitat variables among plots was examined using a Principal Component Analysis (PCA). The three vegetation characteristics of Axis 1 accounting for most of the variability in the PCA analysis were then compared to numbers of $M$. decemlineata captured, using regression analysis. The effect of site and treatment on invertebrate abundance and species richness was evaluated using twoway ANOVA. Regression analysis was used to test the 
relationship between the number of $M$. decemlineata captured and invertebrate abundance and diversity, and the relationship between number of $M$. decemlineata captured and human disturbance (as measured by proximity of the three nearest villages and number of cut trees).

\section{Results}

\section{Distribution}

It is not yet known whether $M$. decemlineata north and south of the Morondava River are the same or different subspecies. For this reason their distributions and population estimates have been considered separately. Results of live-trapping and village interviews indicate that in central Menabe $M$. decemlineata occurs throughout the largest area of connected forest from Kiboy in the north to the southern limits of the Réserve Spéciale d'Andranomena and the forest south of Marofandilia (Fig. 2), and in the west near the villages of Lambokely and Ampataka. The species does not extend into the smaller fragments east of the main area of connected forest in central Menabe, apart from the forest of Longo, south-west of the village of Antsoha. The larger forest fragments north and east of the village of Antsetaka have not supported animals in recent memory ( $>70$ years). The south-eastern limit of the distribution in central Menabe extends to the forests north of Antsondroka but does not continue to the forests south of the village, around Ankiliabo (Fig. 2).

$M$. decemlineata was reported by villagers to be found in most of the fragmented forest in southern Menabe (Fig. 3), although it was considered to be rare in the smaller fragments in the east. M. decemlineata was reportedly common in the largest areas of forest in the west near the villages of Ankoba, Fiadanana and Ampasy, but was not found to the south and east of Malandira. $M$. decemlineata was not present in the fragment of forest north of the village of Ambatovoamba, although it was reported to be in the adjacent forest of Kilandry to the north-east. Most of the large fragments of forest around the village of Laijoby have been cut since 1996 and what does remain is highly degraded. Villagers were not surveyed near Kirindy-Mite as $M$. decemlineata has recently been trapped in this area by other researchers (S. Goodman, unpubl. data). The villagers in Ampasy stated that $M$. decemlineata could be found in the forest immediately south of the village on the other side of the Mangoky River. This represents the first evidence of the existence of $M$. decemlineata south of the Mangoky.

\section{Live-trapping and demography of trapped population}

Fifty-four $M$. decemlineata were trapped in central Menabe. The number of animals captured varied significantly among the four sites $\left(F_{3,4}=15.33, \mathrm{P}=0.01\right)$. Number of animals captured was not significantly different between treatments $\left(F_{1,6}=0.33, \mathrm{P}=0.59\right)$. The greatest numbers were caught in the forestry concession of the Centre de Formation Professionelle Forestière $(\mathrm{CFPF})$ in the Kirindy Forest, with decreasing numbers trapped in the northern and southern limits of the range (Table 2).

Twenty-two of the trapped animals were female (13 adults, 5 juveniles and 4 young) and 30 were male (23 adults and 7 juveniles). The sex of two young animals was not determined. Adult males weighed 475-625 g (mean $539 \pm$ SD $43 \mathrm{~g}$ ). Adult females weighed 450-740 g $(520 \pm$ SD $71 \mathrm{~g})$. Eighty-five percent of the adult females captured were pregnant. Juvenile $M$. decemlineata weighed 350-490 $\mathrm{g}$ (411 \pm SD $43 \mathrm{~g})$. Young of the year weighed 265-335 g (300 \pm SD $30 \mathrm{~g})$.

There was considerable variation in group sizes (Table 3), with the largest groups observed in Kirindy/ CFPF and Amboloando. Single animals were most commonly encountered at the northern and southern sites of Ambatomainty and Joie Roger. Only at Kirindy/ CFPF and Amboloando were groups commonly trapped together or observed travelling within the forest. A group of $>10$ individuals was observed at Kirindy/ CFPF.

\section{Minimum population estimates}

The minimum number of $M$. decemlineata remaining in central Menabe, including adults, juveniles and young, was estimated to be 3,750-4,350, and the number of adults 2,000-3,400 (Table 4). The area of occupancy was $900.22 \mathrm{~km}^{2}$ and the extent of occurrence $1,524 \mathrm{~km}^{2}$. The minimum number of $M$. decemlineata in southern Menabe was estimated to be 7,100-13,150 and the number of adults 6,400-8,650 (Table 4). These estimates are tentative, having been extrapolated from the trapping results in central Menabe. The area of occupancy was $1,871 \mathrm{~km}^{2}$ and the extent of occurrence $8,729 \mathrm{~km}^{2}$.

Table 2 Number of $M$. decemlineata live-trapped in central Menabe in October-November 2002. See Fig. 2 for locations of plots.

\begin{tabular}{|c|c|c|c|c|}
\hline Site & Plot & Treatment $^{1}$ & $\begin{array}{l}\text { Individuals } \\
\text { trapped }\end{array}$ & Recaptures \\
\hline \multirow[t]{2}{*}{ Ambatomainty } & N1 & Exploited & 3 & 0 \\
\hline & $\mathrm{N} 2$ & Unexploited & 3 & 0 \\
\hline \multirow[t]{2}{*}{ Amboloando } & $\mathrm{C} 1$ & Exploited & 7 & 2 \\
\hline & $\mathrm{C} 2$ & Unexploited & 8 & 1 \\
\hline \multirow[t]{2}{*}{ Kirindy/CFPF } & K1 & Exploited & 10 & 3 \\
\hline & $\mathrm{K} 2$ & Unexploited & 13 & $7^{2}$ \\
\hline \multirow[t]{2}{*}{ Joie Roger } & JR1 & Exploited & 4 & 0 \\
\hline & JR2 & Unexploited & 6 & 0 \\
\hline
\end{tabular}

${ }^{1}$ See text for details

${ }^{2}$ One individual was recaptured twice 
Table 3 Group sizes of $M$. decemlineata observed at the study sites in central Menabe (Fig. 2) in October-November 2002. Each group is presented within separate parentheses. Sex and age is given for animals that were trapped and handled. Unknown refers to animals that were observed at a distance but not handled. See Fig. 2 for locations of plots.

\begin{tabular}{|c|c|c|}
\hline Site & Plot/Location & Group size \& demography \\
\hline \multirow[t]{3}{*}{ Ambatomainty } & N1 & (1 juvenile $\widehat{\jmath})(1$ adult $+\& \& 1$ young $\odot$ ) \\
\hline & N2 & 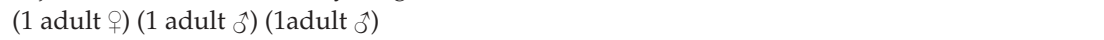 \\
\hline & On road & 5 lone animals seen at different times on the road between the two plots \\
\hline \multirow[t]{3}{*}{ Amboloando } & $\mathrm{C} 1$ & $(1$ adult +$)\left(1\right.$ juvenile + ) $\left(1\right.$ adult $\left.\delta^{\top}\right)(1$ young unknown $)(2 \text { adult }+\& \text { \& juvenile }+)^{1}(4$ unknown $)$ \\
\hline & $\mathrm{C} 2$ & 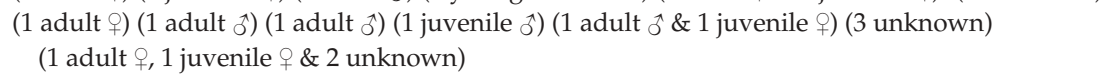 \\
\hline & Road & (1 unknown) (3 unknown) \\
\hline \multirow[t]{3}{*}{ Kirindy/CFPF } & K1 & 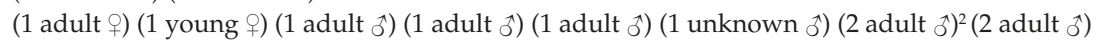 \\
\hline & $\mathrm{K} 2$ & 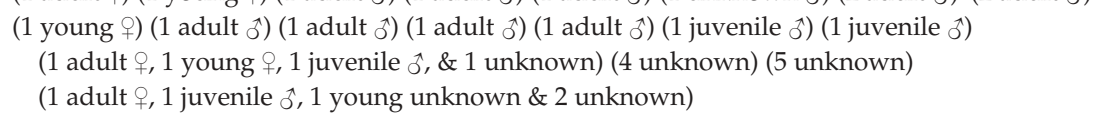 \\
\hline & Road & (1 unknown) (10 unknown) \\
\hline \multirow[t]{3}{*}{ Joie Roger } & JR1 & $(1$ adult $\$)(1$ adult $\widehat{\jmath})(1$ adult $\uparrow \& 1$ adult $\widehat{\jmath})$ \\
\hline & JR2 & 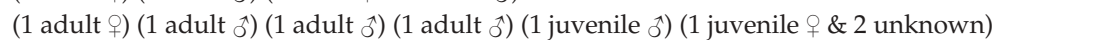 \\
\hline & Road & 4 lone animals seen at different times on the road between the two plots \\
\hline
\end{tabular}

${ }^{1}$ The two adult females were pregnant

${ }^{2}$ These two adult males were caught together on 31 October and were recaptured again together on 1 November. They joined up and left together upon release on both occasions.

Table 4 Minimum population estimates of M. decemlineata in central (Fig. 2) and southern Menabe (Fig. 3) in 2002.

\begin{tabular}{|c|c|c|c|c|c|c|}
\hline \multirow[b]{2}{*}{ Region } & \multirow[b]{2}{*}{ Study site } & \multirow[b]{2}{*}{ Animals km-2 } & \multirow[b]{2}{*}{ Adults $\mathrm{km}^{-2}$} & \multirow{2}{*}{$\begin{array}{l}\text { Area of forest of } \\
\text { similar quality } \\
\text { in region }\left(\mathrm{km}^{2}\right)\end{array}$} & \multicolumn{2}{|c|}{ Population estimate } \\
\hline & & & & & All age classes & Adults \\
\hline Central & Ambatomainty & 3 & $1-3$ & 577.45 & 1,732 & $577-1,732$ \\
\hline \multirow[t]{3}{*}{ Menabe } & Joie Roger & $4-6$ & 4 & 137.80 & $551-827$ & 551 \\
\hline & Amboloando & $7-8$ & $4-5$ & 125.14 & $876-1,001$ & $500-626$ \\
\hline & Kirindy/CFPF & $10-13$ & $6-8$ & 59.83 & $598-778$ & $359-479$ \\
\hline Total & & & & 900.22 & $3,757-4,338$ & $1,987-3,388$ \\
\hline Southern & Ambatomainty & 3 & $1-3$ & 363.41 & 1,090 & $363-1,090$ \\
\hline Menabe & $\begin{array}{l}\text { Amboloando \& } \\
\text { Joie Roger }\end{array}$ & $4-8$ & $4-5$ & $1,507.59$ & $6,030-12,061$ & $6,030-7,538$ \\
\hline Total & & & & 1,871 & $7,120-13,151$ & $6,393-8,628$ \\
\hline
\end{tabular}

\section{Forest structure}

There was little variation in habitat variables among plots, with Axis 1, 2 and 3 of the PCA accounting for $16.3,14.4$ and $10.2 \%$ of the variance, respectively. For Axis 1 , the abundance of lianas (Loading $=0.767$ ), visibility (-0.738), and number of trees $<5 \mathrm{~m}$ in height $(-0.622)$ accounted for most of the variability. However, these three variables had no linear relationship with the number of animals captured at each plot (liana abundance $r^{2}=0.11, \mathrm{P}=0.43$; visibility $r^{2}=0.16, \mathrm{P}=0.33$; trees $\left.<5 \mathrm{~m} \mathrm{r}^{2}=0.43, \mathrm{P}=0.09\right)$. Soil structure and litter depth, two variables considered important for $M$. decemlineata because of their reliance on insect larvae as a food source (Rabeantoandro, 1997), did not vary among the plots. Soil was primarily ferruginous, sandy and either yellowish brown or greyish beige. Humus was poorly developed and leaf litter depth $<2 \mathrm{~cm}$ at all sites.

\section{Invertebrate sampling}

A total of 322 invertebrates comprising 76 different species were captured in the pitfall traps. The most abundant and diverse groups of invertebrates caught were crickets and cockroaches (Orthoptera) and spiders (Araneida). No significant differences were found among sites or between treatments for abundance (site $F_{3,12}=0.10, \mathrm{P}=0.95$; treatment $F_{1,14}=0.10, \mathrm{P}=0.76$; site * treatment $F_{3,12}=0.78, \mathrm{P}=0.54$ ) or diversity (site $F_{3,12}=0.42, \mathrm{P}=0.74$; treatment $F_{1,14}=0.92, \mathrm{P}=0.37$; site * treatment $\left.F_{3,12}=0.42, \mathrm{P}=0.74\right)$. There was no linear 
relationship between number of $M$. decemlineata captured and invertebrate abundance $\left(r^{2}=0.03, \mathrm{P}=0.71\right)$ or diversity $\left(r^{2}=0.03, \mathrm{P}=0.48\right)$.

\section{Human disturbance}

Proximity of the three nearest villages $\left(r^{2}=0.03\right.$, $\mathrm{P}=0.99)$ or number of cut trees $\left(r^{2}=0.01, \mathrm{P}=0.91\right)$ had no linear relationship to the number of $M$. decemlineata captured. However, the greatest densities of $M$. decemlineata were found in the two study plots at Kirindy/ CFPF, which was the only site where neither people nor dogs were observed during the trapping session.

\section{Discussion}

M. decemlineata was found throughout the larger fragments of dry deciduous forest in central and southern Menabe, and the number of animals trapped did not appear to be related to variation in forest structure or leaf litter invertebrate abundance and diversity. Significant differences in numbers of $M$. decemlineata were not found between treatments (exploited and unexploited areas), but were found between study sites with differing levels of human disturbance. The building of access roads for logging may have an effect that extends beyond the immediate period and locality of commercial activity by increasing the level of human activity within the surrounding uncut areas.

In central Menabe there is little likelihood that $M$. decemlineata is to be found in viable population numbers in the smaller fragments east of the remaining larger area of connected forest. Even this larger area is under extreme pressure from slash-and-burn agriculture and is being reduced to smaller fragments, particularly in the south-east and in the area east of Beroboka. In southern Menabe M. decemlineata still occurs in the smaller fragments of forest in the east, but this forest is rapidly disappearing. The only substantial populations remain in the larger western fragments. A report that M. decemlineata is being hunted for food in southern Menabe (Goodman \& Raselimanana, 2003) could indicate that the rate of decline will increase.

The number of animals captured in central Menabe varied significantly among the four sites but not between treatments, suggesting that geography (i.e. the site) was more important than the presence or absence of exploitation (i.e. the treatment). The greater number of recaptures in Kirindy/CFPF and Amboloando suggests that these represent populations resident within the study plots, whereas the lack of recaptures in the northern and southern study plots implies that non-resident animals were being trapped. The healthiest populations (i.e. with the largest number of animals and largest group sizes) were within the least disturbed areas of Kirindy/CFPF. Increased human disturbance may be disrupting the social dynamics of $M$. decemlineata at the limits of its range. The gregarious nature of this animal is one of the distinguishing features of the species (Albignac, 1973, 1976). The lack of recaptures and observations of social units in the northern and southern limits of central Menabe suggests that individuals in these areas were transient and solitary. $M$. decemlineata at the edges of its range or in relatively small forest fragments may be under increased levels of stress and exist in low densities.

The absence of variation in forest structure among plots was not unexpected as the plots were within intact, dry, deciduous forest of similar overall structure within the limited range of $M$. decemlineata. These results suggest that the forest at all sampled sites was of adequate quality to support $M$. decemlineata, and that neither variation in forest structure nor number of individuals or species of invertebrates in leaf litter accounted for differences in numbers of Mungotictis caught.

It was difficult to show empirically within the scope of the present study how commercial forest cutting may be affecting $M$. decemlineata. There are confounding variables such as the number of roads created by commercial cutting, dependence on forest products by local villages, and level of unregulated activity by non-local villagers, primarily the cutting of trees for construction and building of pirogues. Commercial cutting may be having an impact on the surrounding forest that extends beyond the immediate period and locality of commercial activity. In particular, building of new roads may accelerate illegal cutting within the surrounding forest, and increase the level of human disturbance and activity by domestic dogs. Roaming dogs are suspected to have a significant impact on terrestrial endemic animals in the Menabe region, including the Malagasy giant jumping rat Hypogeomys antimena (Sommer et al., 2002). Although no empirical study has yet been carried out, sightings of $M$. decemlineata increased significantly at the CFPF Kirindy field station following the removal of dogs from the area (F. Hawkins, pers. comm.). An evaluation of the impact of predation by dogs on $M$. decemlineata should be a priority.

The healthiest population of $M$. decemlineata was found within the least disturbed forest of Kirindy/CFPF, suggesting that human activity is a critical factor limiting numbers within the remaining areas of intact forest in the Menabe region. If this is the case, M. decemlineata will require areas that are protected from unregulated use by both local and non-local villagers.

Based on our findings we identify three main conservation needs for the survival of the narrow-striped mongoose M. decemlineata: 
1) The rapid loss and fragmentation of forest habitat is the most immediate threat. Conservation organizations must increase cooperative efforts with local villages to reduce the rates of slash-and-burn agriculture and commercial logging in the remaining dry deciduous forest of Menabe. Emphasis must be placed on halting the deforestation east of Beroboka, which is dividing the largest remaining area of intact forest. There are two legally protected areas within the current range of the species, the Réserve Spéciale $\mathrm{d}^{\prime}$ Andranomena $\left(64 \mathrm{~km}^{2}\right)$ in central Menabe and the Parc National de Kirindy-Mite $\left(722 \mathrm{~km}^{2}\right)$ in southern Menabe. Together they represent $7.7 \%$ of the estimated area of occurrence of $M$. decemlineata. Unfortunately, Andranomena consists entirely of secondary and degraded forest and Kirindy-Mite has been significantly affected by hunting (Goodman \& Raselimanana, 2003). A protected area needs to be established that encompasses Kirindy/CFPF, the remaining corridor of forest east of Beroboka, and the forest of Ambadira north of Beroboka. This would also benefit the other species endemic to the Menabe region.

2) In southern Menabe the remaining deciduous forest is disappearing rapidly and is increasingly fragmented, and more information is required on the distribution and status of $M$. decemlineata in this region. A live-trapping study should be carried out to determine population trends and subspecific status of $M$. decemlineata in the remaining forest fragments, and the degree of threat posed by hunting of $M$. decemlineata for food requires evaluation.

3) The full distribution and taxonomic status of $M$. decemlineata, and in particular whether $M$. d. lineata is a distinct subspecies and if its range is south of the Mangoky River, requires investigation. If a population (or subspecies) does exist south of the River, it is probably facing pressures similar to those facing $M$. decemlineata in Menabe.

The Durrell Wildlife Conservation Trust (DWCT), the Malagasy NGO Fanamby, Conservation International and WWF-Madagascar continue to work with local villages in Menabe to halt the current rates of slashand-burn agriculture through community awareness programmes and implementation of methods of sustainable resource use. Fanamby and the DWCT have worked with the new regional authorities and local people to agree on a protected area covering 100,000 ha of forests and wetlands in central Menabe. This protected area, which should receive legal protection by the end of 2005, includes a priority conservation zone with no extractive use of 30,250 ha covering Kirindy/CFPF, the remaining corridor of forest east of Beroboka and the forest of
Ambadira north of Beroboka. Research is currently underway at the Department of Ecology and Evolutionary Biology, Yale University, to determine the subspecific status of Mungotictis and examine gene flow between populations in central and southern Menabe and to investigate the taxonomy and conservation status of Mungotictis south of the Mangoky River.

\section{Acknowledgements}

We thank Fernandel, Richard Mozavelo and Mbaraka Mohamed for their outstanding assistance in the field. Research was funded by Wildlife Preservation Canada, Durrell Wildlife Conservation Trust, Conservation International, and Fanamby. Richard Lewis, Jonah Ratsimbazafy, Leon Razafimanantsoa, Steven Goodman, Frank Hawkins and Simone Sommer provided invaluable advice throughout. We thank Marlene Snyder, Ian Paterson, Michael O'Brien and Peter Austin-Smith Jr for providing some of the field equipment. The staff at the Deutsches Primatenzentrum provided invaluable assistance. John Hartley, Anna Feistner and Valerie Harding provided support from Durrrell Wildlife Conservation Trust. Steve Goodman, Frank Hawkins, Will Duckworth, Harry Van Rompaey, Anna Feistner and two anonymous reviewers provided significant comments on earlier drafts.

\section{References}

Albignac, R. (1973) Mammiferes Carnivores. Faune de Madagascar 36. ORSTOM/CNRS, Paris, France.

Albignac, R. (1976) L'écologie de Mungotictis decemlineata dans les forêts decidues de l'ouest de Madagascar. La Terre et La Vie, 30, 347-376.

Goodman, S. \& Raselimanana, A. (2003) Hunting of wild animals by Sakalava of the Menabe region: a field report from Kirindy-Mite. Lemur News, 8, 4-5.

Gray, J.E. (1848) Description of a New Species of Galidictis from Madagascar. Proceedings of the Zoological Society of London, XX, 21-23, London, UK.

Hawkins, A.F.A., Hawkins, C. \& Jenkins, P.D. (2000) Mungotictis decemlineata lineata (Carnivora:Herpestidae), a mysterious Malagasy mongoose. Journal of Natural History, 34, 305-310.

IUCN (2001) 2001 Categories and Criteria (version 3.1). IUCN, Gland, Switzerland [http:/ / www.redlist.org/info/ categories_criteria2001.html, accessed 1 November 2005].

IUCN (2004) IUCN Red List of Threatened Species. IUCN, Gland, Switzerland [http:/ / www.redlist.org, accessed 18 August 2005].

Krebs, C.J. (1999) Ecological Methodology. 2nd edition. Addison-Welsey Educational Publishers, Menlo Park, USA.

Rabeantoandro, Z. (1997) Contribution à l'étude biologique et écologique de Mungotictis decemlineata decemlineata (Grandidier, 1869) dans la forêt de Kirindy à Morondava. Mémoire pour l'obtention de D.E.A., Université d'Antananarivo, Faculté des Sciences, Madagascar. 
Razafimanantsoa, L. (2003) Mungotictis decemlineata, narrow-striped mongoose. In A Natural History of Madagascar (eds S.M. Goodman \& J.P. Benstead), pp. 1357-1360. University of Chicago Press, Chicago, USA.

Sommer, S., Toto Volahy, A. \& Seal, U.S. (2002) A population and habitat viability assessment for the highly endangered giant jumping rat (Hypogeomys antimena), the largest extant endemic rodent of Madagascar. Animal Conservation, 5, 263-273.

Tidd, S., Pinder, J. \& Ferguson, G. (2001) Deforestation and habitat loss for the Malagasy flat-tailed tortoise from 1963 through 1993. Chelonian Conservation and Biology, 4, 59-65.

\section{Biographical sketches}

Lance Woolaver is currently studying the conservation genetics of endangered avifauna in the Dominican Republic. He is a member of the IUCN/SCC Re-introduction Specialist Group. He has released echo parakeets and pink pigeons in Mauritius, and California condors and loggerhead shrikes in North America.

Rina Nichols is the Species Recovery Biologist for Wildlife Preservation Canada. She has carried out field research on critically endangered species in North America, Madagascar, Mauritius and the Dominican Republic.

William F. Rakotombololona is a conservation coordinator for the Durrell Wildlife Conservation Trust and carries out community-based events and field research on endangered species within the Menabe region of Madagascar.

Anselme T. Volahy is a biologist for the Durrell Wildlife Conservation Trust and works on the assessment of conservation status and monitoring of endangered species within the Menabe region of Madagascar.

Joanna Durbin is Programme Director for the Durrell Wildlife Conservation Trust in Madagascar. 